\title{
Glass-metal particulate composites
}

\author{
D CHAKRAVORTY* \\ Central Glass and Ceramic Research Institute, Calcutta, 700032, India \\ * On leave of absence from Indian Institute of Technology, Kanpur
}

\begin{abstract}
Oxide glasses containing ultrafine metal particles have interesting physical properties and have been widely used in practical systems. The various preparational techniques developed so far for making these materials are discussed. Electrical conduction in these composites is controlled by electron tunnelling between the metal islands. At high electric fields certain glasses containing bismuth granules show a memory switching effect. The latter has been explained by a particle stretching model. Optical absorption characteristics of these composites can be explained on the basis of various effective medium theories developed so far for inhomogeneous materials. Glasses containing ferromagnetic metal grains show a superparamagnetic behaviour with a transition temperature below $300 \mathrm{~K}$. Improvement in the mechanical properties of glasses can be achieved by incorporating metal particles of suitable characteristics within them. In this paper the present state of understanding of all these properties is reviewed.
\end{abstract}

Keywords. Glass-metal composites; oxide glasses; composites; electrical properties; optical properties; magnetic properties; mechanical properties.

\section{Introduction}

Glasses containing colloidal metal particles of dimensions of the order of a few hundred angstroms have found extensive uses in the preparation of photosensitive glasses, glassceramics (Araujo 1977) coloured glasses (Rawson 1980), photochromic glasses (Araujo 1977), thermally darkenable photochromic glasses (Seward 1975) and polychromatic glasses (Stookey et al 1978). These materials are prepared by photo-chemical methods. Ion-exchange followed by reduction treatments have also been found to be suitable for this purpose (Chakravorty et al 1975). Recent investigations show the possibility of inducing electronic conductivity to oxide glasses by precipitating metal granules within them (Chakravorty 1981). Some of these micro-composites also exhibit memory switching (Chakravorty 1975). Glasses containing ultra-fine ferromagnetic metal particles exhibit superparamagnetic behaviour (Datta et al 1983a). Glass-metal composite systems have also been studied in recent years to obtain improvement in the toughening of oxide glasses (Krstic 1981). A powder metallurgy technique however was used to make the composites for the study of their mechanical behaviour. In this paper we review the recent advances made in the understanding of the preparation and properties of glass-metal particulate composites.

\section{Preparation of glass-metal particulate composites}

There are broadly two different techniques for making the composites under discussion. The first is essentially a chemical one, whereas the second is based on hot pressing of a powder compact. 
Metal particles are precipitated in photosensitive glasses by irradiating them with UV radiation and then heating the glasses at a suitable temperature (Araujo 1977). Some sensitizer e.g., $\mathrm{CeO}_{2}, \mathrm{Sb}_{2} \mathrm{O}_{3}$ which has a variable valence ion is included in the glass compositions to increase their photosensitivity. Similar method is employed in the preparation of photochromic (Armistead and Stookey, 1965) and polychromatic glasses (Stookey et al 1978). A typical reaction involving the precipitation of silver by irradiation from a heat-treated photochromic glass containing a dispersion of silver chloride crystals can be represented by

$$
\mathrm{Ag}^{+}+\mathrm{Ce}^{3+}+\mathrm{hv} \rightarrow \mathrm{Ag}^{\circ}+\mathrm{Ce}^{4+} \text {. }
$$

Colloidal metal particles of copper, silver, gold, platinum and bismuth can be precipitated in oxide glasses by melting a suitable salt of the metal along with the relevant oxides for the specific glass composition and some reducing agents like $\mathrm{SnO}$ or $\mathrm{Sb}_{2} \mathrm{O}_{3}$ (McMillan 1979; Chakravorty et al 1977). The precipitation of a metal phase from a dissolved ion in an oxide glass melt can be considered to be an equilibrium situation. It has been shown specifically in the case of formation of iron, cobalt and nickel metal phase in a borosilicate glass melt that an equilibrium between metal and dissolved ion is established over a range of oxygen fugacities at a particular temperature (Schreiber 1983). These ions are introduced into the glass melt as their respective oxides. Some recent investigation show that metal phase can be precipitated in an oxide glass by melting the latter with an organometallic compound containing the metallic species (Datta and Chakravorty 1983). A borate glass with nickel granules has been made using nickel oxinate as one of the raw materials. This method appears to be suitable for making various glass-metal microcomposites by a melting operation under ordinary atmospheric condition. It is believed that favourable oxygen fugacities are attained locally within the melt because of the breaking up of the organometallic compound releasing carbon, hydrogen and nitrogen atoms.

Metallic particles can also be precipitated within an alkali-containing glass by subjecting the latter to an ion-exchange and reduction treatment (Chakravorty et al 1975). The ion-exchange reaction is carried out by immersing the glass in a molten sait bath containing the required ion for a suitable duration. The reduction of the ionexchanged surface is brought about by passing a mixture of nitrogen and hydrogen gases over it for a specific period. Sodium $\rightleftharpoons$ copper (Chakravorty et al 1975) and sodium $\rightleftharpoons$ silver (Sarkar et al 1982) exchange in silicate glasses have been investigated in detail. It is observed that the precipitation of metal grains within the glass is controlled by a nucleation and growth process. Accordingly there is an optimum reduction temperature at which the nucleation rate is a maximum. Table 1 summarises the nucleation temperature data etc. for various systems studied so far. It is also found that the phase morphology of the glass after the ion exchange step has a pronounced effect on the subsequent metal precipitation. For instance, the metal dispersoids are observed to be concentrated in the interconnected metal rich phase in sodium $\rightleftharpoons$ copper exchanged float glass (Chakravorty et al 1975).

Glass-metal particulate composites have also been prepared by hot-pressing of a mixture of glass powder and metal particles (Krstic et al 1981; Stett and Fulrath 1968; Nivas and Fulrath 1970). Silicate glasses have been used with metallic particles of nickel (Krstic et al 1981; Stett and Fulrath 1968), tungsten (Nivas and Fulrath 1970) and aluminium (Krstic et al 1981) respectively the latter having diameters in the range $40 \mu \mathrm{m}-120 \mu \mathrm{m}$. To improve the bonding between the metallic particles and the glass 
Table 1. Reduction temperature for maximum nucleation of metal phase in different ionexchanged glasses

\begin{tabular}{|c|c|c|c|c|}
\hline \multirow{2}{*}{$\begin{array}{l}\text { Glass } \\
\text { system }\end{array}$} & \multicolumn{2}{|c|}{ Ion-exchange treatment } & \multirow{2}{*}{$\begin{array}{c}\text { Reduction } \\
\text { temperature } \\
\text { for maximum } \\
\text { nucleation }\end{array}$} & \multirow{2}{*}{ Reference } \\
\hline & Species & Temperature/time & & \\
\hline Float glass & $\mathrm{Na}^{+} \rightleftharpoons \mathrm{Cu}^{+}$ & $550^{\circ} \mathrm{C} / 1 \mathrm{hr}$ & $450^{\circ} \mathrm{C}$ & $\begin{array}{l}\text { Chakravorty et al } \\
1975 \text {. }\end{array}$ \\
\hline $\begin{array}{l}\ldots \\
\ldots\end{array}$ & $\begin{array}{l}\cdots \\
\cdots\end{array}$ & $\begin{array}{l}660^{\circ} \mathrm{C} / 1 \mathrm{hr} \\
650^{\circ} \mathrm{C} / 1 \mathrm{hr}\end{array}$ & $\begin{array}{l}\ldots \\
\ldots\end{array}$ & \\
\hline C-glass & $\mathrm{Na}^{+} \rightleftharpoons \mathrm{Ag}^{+}$ & $330^{\circ} \mathrm{C} / 6 \mathrm{hr}$ & $250^{\circ} \mathrm{C}$ & (Sarkar et al 1982) \\
\hline$\cdots$ & $\cdots$ & $\cdots$ & $\cdots$ & \\
\hline $\begin{array}{l}64 \mathrm{SiO}_{2}, 26 \mathrm{~B}_{2} \mathrm{O}_{3}, \\
10 \mathrm{Na}_{2} \mathrm{O} \text { (mole }\end{array}$ & $\begin{array}{l}\cdots \\
\cdots\end{array}$ & $\begin{array}{l}\cdots \\
\cdots\end{array}$ & $300^{\circ} \mathrm{C}$ & (Sarkar et al 1982) \\
\hline
\end{tabular}

matrix the former are oxidised in air prior to mixing with the glass for subsequent hotpressing operation. The mixtures are then vacuum hot-pressed-typical temperature and pressure being $500-700^{\circ} \mathrm{C}$ and $0 \cdot 3 \mathrm{MPa}$ respectively (Krstic et al 1981). Glass compositions have been chosen such that their thermal expansion coefficients are of the same order of magnitude as those of the metallic species concerned.

One of the most important aspects in the preparation of glass-metal particulate composites is the glass-to-metal interfacial bonding. A number of studies have been reported on the wetting of metals by molten glasses using sessile drop technique (Pask and Fulrath 1970; Nagesh et al 1983) under controlled atmospheres. It is believed that a strong chemical bond at the interface requires the presence of a transition layer consisting of metal atoms exhibiting both metallic and ionic-covalent bonds and oxygen atoms which are also part of the glass structure. In the absence of such a zone at the interface a weaker bond of the van der Waals type exists which causes a poor adherence of the metal phase to the glass.

\section{Properties of glass-metal particulate composites}

\subsection{Electrical}

Electrical conduction in glass-metal composites with metal grains having sub-micron dimensions has been explained as arising due to the transport of electrons by tunnelling from one metal grain to the next (Chakravorty 1977). The theoretical model which has been used to analyse the experimental results obtained for these materials is identical to that developed for electrical conduction in granular metal films or cermets (Abeles et al 1976). According to this model, the generation of a charge carrier viz electron involves the creation of a pair of positively and negatively changed grains. The energy $E_{c}^{0}$ to create such a pair is given by

$$
E_{c}^{0}=2 e^{2} / K d
$$

where $e$ is the electronic charge, $d$ the metal grain diameter and

$$
K=\varepsilon[1+(d / 2 s)]
$$


$\varepsilon$ being the dielectric constant of the insulating matrix and $s$ the inter-particle separation.

The mobility of the charge carrier in the present system is proportional to the tunnelling probability exp $(-2 \chi s)$ where,

$$
\chi=\left[2 m \phi / \hbar^{2}\right]^{1 / 2}
$$

$m$ being the electronic mass, $\phi$ the effective barrier height and $h$ the Planck's constant. The conductivity $\sigma$ can therefore be written as (Abeles et al 1976)

$\sigma \propto \int_{0}^{\infty} \beta(s) \exp [-2 \chi s-(C / 2 \chi s k T)]$

where $C \equiv \chi s E_{c}^{o}$

and $\beta(\mathrm{s})$ is the density of percolation paths associated with $s$. Abeles et al (1976) have shown that by making certain approximations, (5) can be simplified to the form,

$$
\sigma=\sigma_{0} \exp \left[-2(C / k T)^{\frac{1}{2}}\right] \text {. }
$$

The variation of electrical resistivity as predicted by the above equation has been found to be valid in various glass-metal systems. Table 2 summarises the $E_{c}^{0}$ values for different systems as obtained from the experimental data. The table also gives the calculated $E_{c}^{0}$ values using the average diameters of metal islands as estimated from electron microscopic investigations. Table 3 summarises the results obtained on some glass fibres in which silver granules have been precipitated by subjecting the former to a

\begin{tabular}{|c|c|c|c|c|c|}
\hline \multirow{2}{*}{$\begin{array}{l}\text { Glass } \\
\text { composition } \\
\text { (mole \%) }\end{array}$} & \multirow{2}{*}{$\begin{array}{l}\text { Metallic } \\
\text { species }\end{array}$} & \multirow{2}{*}{$\begin{array}{l}\text { Average } \\
\text { particle } \\
\text { diameter } \\
\text { (A) }\end{array}$} & \multicolumn{2}{|c|}{$E_{c}^{0}$} & \multirow[t]{2}{*}{ Reference } \\
\hline & & & $\begin{array}{l}\text { Expt. } \\
(\mathrm{eV})\end{array}$ & $\begin{array}{l}\text { Calc. } \\
(\mathrm{eV})\end{array}$ & \\
\hline $\begin{array}{l}64 \mathrm{SiO}_{2} 18 \mathrm{~B}_{2} \mathrm{O}_{3} \\
8 \quad \mathrm{Bi}_{2} \mathrm{O}_{3} 10 \mathrm{Na}_{2} \mathrm{O}\end{array}$ & Bismuth & 50 & $4.0 \times 10^{-2}$ & $9.0 \times 10^{-2}$ & $\begin{array}{l}\text { (Chakravorty } \\
\text { et al 1977) }\end{array}$ \\
\hline $\begin{array}{l}80 \mathrm{~V}_{2} \mathrm{O}_{5} 15 \mathrm{P}_{2} \mathrm{O}_{5} \\
5 \mathrm{Bi}_{2} \mathrm{O}_{3}\end{array}$ & $\ldots$ & 50 & $1.2 \times 10^{-2}$ & $1.3 \times 10^{-2}$ & $\begin{array}{l}\text { (Chakravorty } \\
\text { et al 1979) }\end{array}$ \\
\hline $\begin{array}{l}70 \mathrm{~V}_{2} \mathrm{O}_{5} 15 \mathrm{P}_{2} \mathrm{O}_{5} \\
15 \mathrm{Bi}_{2} \mathrm{O}_{3}\end{array}$ & $\ldots$ & 100 & $4.7 \times 10^{-3}$ & $3.9 \times 10^{-3}$ & $\ldots$ \\
\hline $\begin{array}{l}75 \mathrm{~V}_{2} \mathrm{O}_{5} 15 \mathrm{P}_{2} \mathrm{O}_{5} \\
10 \mathrm{Ag}_{2} \mathrm{O}\end{array}$ & Silver & 200 & $1.6 \times 10^{-3}$ & $1.6 \times 10^{-3}$ & $\ldots$ \\
\hline $\begin{array}{l}85 \mathrm{~B}_{2} \mathrm{O}_{3} 5 \quad \mathrm{Na}_{2} \mathrm{O} \\
10 \mathrm{Bi}_{2} \mathrm{O}_{3}\end{array}$ & Bismuth & 120 & $1.4 \times 10^{-2}$ & $1.5 \times 10^{-2}$ & $\begin{array}{l}\text { (Chakravorty and } \\
\text { Chakrabarti } \\
\text { 1980) }\end{array}$ \\
\hline $\begin{array}{l}75 \mathrm{~B}_{2} \mathrm{O}_{3} 20 \mathrm{PbO} \\
5 \mathrm{Bi}_{2} \mathrm{O}_{3}\end{array}$ & $\cdots$ & 400 & $4.2 \times 10^{-3}$ & $3.8 \times 10^{-3}$ & $\cdots$ \\
\hline $\begin{array}{l}46 \mathrm{SiO}_{2} 25 \mathrm{~B}_{2} \mathrm{O}_{3} \\
11 \mathrm{~K}_{2} \mathrm{O} 9 \mathrm{Al}_{2} \mathrm{O}_{3}\end{array}$ & Silver & 500 & $1.7 \times 10^{-2}$ & $2.2 \times 10^{-2}$ & $\begin{array}{l}\text { (Chakravorty } \\
\text { et al 1979b) }\end{array}$ \\
\hline 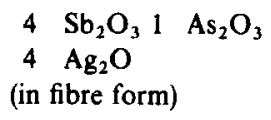 & & & & & \\
\hline
\end{tabular}

Table 2. $E_{c}^{0}$ values in various glass-metal particulate systems 
Table 3. $E_{c}^{0}$ values in glass-metal particulates produced by ion-exchange and reduction treatments

\begin{tabular}{|c|c|c|c|c|c|c|}
\hline \multirow{2}{*}{$\begin{array}{l}\text { Glass } \\
\text { composition } \\
\text { (mole \%) }\end{array}$} & \multirow{2}{*}{$\begin{array}{l}\text { Ion- } \\
\text { exchanging } \\
\text { species }\end{array}$} & \multirow{2}{*}{$\begin{array}{c}\text { Metallic } \\
\text { species }\end{array}$} & \multirow{2}{*}{$\begin{array}{l}\text { Average } \\
\text { particle } \\
\text { diameter } \\
\text { (A) }\end{array}$} & \multicolumn{2}{|c|}{$E_{c}^{0}$} & \multirow[t]{2}{*}{ Reference } \\
\hline & & & & $\begin{array}{c}\text { Experimental } \\
\text { (eV) }\end{array}$ & $\begin{array}{l}\text { Calculated } \\
(\mathrm{eV})\end{array}$ & \\
\hline $\begin{array}{l}64 \mathrm{SiO}_{2} \\
26 \mathrm{~B}_{2} \mathrm{O}_{3} \\
10 \mathrm{Na}_{2} \mathrm{O}\end{array}$ & $\begin{array}{l}\text { Sodium } \rightleftharpoons \\
\text { silver }\end{array}$ & Silver & 115 & $8.7 \times 10^{-3}$ & $2.3 \times 10^{-2}$ & $\begin{array}{l}\text { (Arul Mozhi } \\
\text { and } \\
\text { Chakravorty } \\
\text { 1982) }\end{array}$ \\
\hline $\begin{array}{l}\text { Commercial } \\
\text { C-glass }\end{array}$ & $\ldots$ & $\ldots$ & 160 & $1.5 \times 10^{-2}$ & $1.9 \times 10^{-2}$ & $\ldots$ \\
\hline
\end{tabular}

sodium $\rightleftharpoons$ silver ion exchange followed by reduction (Arul Mozhi and Chakravorty 1982). In all cases, the experimental and calculated values of $E_{c}^{0}$ are found to be in reasonable agreement.

Some oxide glasses containing fine bismuth particles exhibit memory switching with a threshold field of the order of $10^{4} \mathrm{~V} / \mathrm{cm}$ (Chakravorty and Murthy 1975) the samples changing their resistivity by about two to three orders of magnitude. Typical resistivity values in the off and on-states are $10^{4} \Omega \mathrm{cm}$ and $5 \Omega \mathrm{cm}$ respectively for a silicate glass containing bismuth (Chakravorty and Murthy 1975). The corresponding values in a vanadium phosphate glass containing bismuth are $250 \Omega \mathrm{cm}$ and $3 \Omega \mathrm{cm}$ respectively (Das and Chakravorty 1980, 1982). The switched samples can be brought back to the off-state by either applying a pulse of large amplitude and small width or by heating them above $\sim 200^{\circ} \mathrm{C}$ and then quenching the same (Chakravorty and Murthy 1975). A particle stretching model has been developed to explain the memory switching behaviour of these glass-metal particulate composites (Das and Chakravorty 1980, 1982). According to this theory, the joule losses in the off-state cause the metal grains to get heated. When these attain a molten state they are subjected to two opposing forces, one of which is due to the coulombic attraction between polarized neighbouring grains and the other arising out of the surface tension force in the molten particles. Under equilibrium condition the molten particles are deformed and the critical or switching field is reached when the interparticle separation becomes equal to zero. An implicit approximation in this model is that there are some filamentary regions across the sample extending from one electrode to the other in which the metal grains have small inter-particle separation. At the threshold field therefore grains in these regions coalesce giving rise to filamentary conducting paths in the sample which bring about switching to the highly conducting on-state. The threshold field $E_{t}$ in this model has been shown (Das and Chakravorty 1980) to be given by,

$$
E_{t}=\left(1+\frac{d}{s_{0}}\right)^{-1}\left\{\frac{8 \gamma}{\varepsilon d}\left[\left(1+\frac{s_{0}}{d}\right)-\left(1+\frac{s_{0}}{d}\right)^{1 / 2}\right]\right\}
$$

where, $s_{0}$ is the average inter-particle separation, $\gamma$ is the specific surface energy of metal glass interface, and $\varepsilon$ is the dielectric permittivity of glass matrix.

In table 4 the experimental and theoretical switching fields for two glass-metal systems are shown. The agreement between the two sets of values is found to be 
Table 4. Switching fields in different glass-metal particulate systems

\begin{tabular}{|c|c|c|c|c|c|}
\hline \multirow{2}{*}{$\begin{array}{l}\text { Glass } \\
\text { composition } \\
\text { (mole } \% \text { ) }\end{array}$} & \multirow{2}{*}{$\begin{array}{r}\text { Metallic } \\
\text { species }\end{array}$} & \multirow{2}{*}{$\begin{array}{l}\text { Maximum } \\
\text { diameter } \\
\text { of metal } \\
\text { granules } \\
\text { (A) }\end{array}$} & \multicolumn{2}{|c|}{$E_{t}$} & \multirow[t]{2}{*}{ Reference } \\
\hline & & & $\begin{array}{l}\text { Experimental } \\
(\mathrm{V} / \mathrm{cm})\end{array}$ & $\begin{array}{c}\text { Theoretical } \\
\text { (V/cm) }\end{array}$ & \\
\hline $\begin{array}{r}64 \mathrm{SiO}_{2} 18 \mathrm{~B}_{2} \mathrm{O}_{3} \\
8 \mathrm{Bi}_{2} \mathrm{O}_{3} \quad 10 \mathrm{Na}_{2} \mathrm{O}\end{array}$ & Bismuth & 500 & $1.2 \times 10^{4}$ & $\begin{array}{c}1.1 \times 10^{4} \\
\left(s_{o / d}=0.03\right)\end{array}$ & $\begin{array}{l}\text { (Das and } \\
\text { Chakravorty } \\
1980 \text { ) }\end{array}$ \\
\hline $\begin{array}{l}80 \mathrm{~V}_{2} \mathrm{O}_{5} 15 \mathrm{P}_{2} \mathrm{O}_{5} \\
5 \mathrm{Bi}_{2} \mathrm{O}_{3}\end{array}$ & $\ldots$ & 800 & $4.0 \times 10^{3}$ & $\begin{array}{c}5.1 \times 10^{3} \\
\left(s_{o / d}=0.03\right)\end{array}$ & $\begin{array}{l}\text { (Das and } \\
\text { Chakravorty } \\
1980 \text { ) }\end{array}$ \\
\hline
\end{tabular}

reasonable. This model also satisfactorily explains the negative resistance behaviour of these glass-metal systems prior to attaining the on-state (Das and Chakravorty 1982).

\subsection{Optical}

Heterogeneous materials exhibit optical properties which are dependent on the relative dielectric permittivities of the different phases present in the system (Landauer 1978). The glass-metal particulate composites with metal granules having dimensions of the order of a few hundred "angstroms also show characteristic optical absorption". Table 5 summarises the results reported so far on optical properties of various glass-metal systems. The Maxwell Garnett and Bruggeman effective medium theories have been used to calculate the optical absorption spectra of these materials which agree qualitatively with the experimental data (Datta et al 1983; Das 1982; Sarker et al 1982).

\subsection{Magnetic}

Recently magnetic properties of a borate glass containing up to $0.4 \mathrm{wt} \%$ nickel dispersed as metal granules of diameters around $70 \mathrm{~A}$ within the matrix have been reported (Datta et al 1983). The ultrafine nickel particles exhibit a superparamagnetic behaviour. Both EPR and magnetization measurements indicate that there exists a broad range of transition temperatures below $300 \mathrm{~K}$. The mean values of the transition temperatures as obtained from EPR and magnetisation data are around $190 \mathrm{~K}$ and $90 \mathrm{~K}$ respectively. The transition has been explained as arising due to the interaction between the magnetic particles which generates a field analogous to the Lorentz field in Debye's theory of polar molecules (Soffge and von Horsten 1981).

\subsection{Mechanical}

Mechanical properties of glass-metal particulate composites have been extensively investigated with a view to achieving improved toughness in these materials (Krstic et al 1981; Stett and Fulrath 1968; Nivas and Fulrath 1970). However, it has not been possible to gain substantial improvement because of the presence of residual stresses and/or poor interfacial bonding between the metal and the glass phases. The residual stresses can be minimised by choosing a glass with a thermal expansion coefficient 
Table 5. Optical absorption in different glass-metal particulate composites

\begin{tabular}{|c|c|c|c|c|c|}
\hline $\begin{array}{l}\text { Glass } \\
\text { systems }\end{array}$ & $\begin{array}{r}\text { Metallic } \\
\text { species }\end{array}$ & $\begin{array}{l}\text { Preparation } \\
\text { technique }\end{array}$ & $\begin{array}{l}\text { Particle } \\
\text { diameter } \\
\text { range } \\
\text { (A) }\end{array}$ & $\begin{array}{l}\text { Wavelength } \\
\text { for absorption } \\
\text { maximum } \\
(\mathrm{nm})\end{array}$ & Reference \\
\hline Float glass & Copper & $\begin{array}{c}\text { Sodium } \rightleftharpoons \\
\text { copper } \\
+ \\
\text { Reduction }\end{array}$ & $50-300$ & $\begin{array}{l}434 \text { and } \\
574\end{array}$ & $\begin{array}{l}\text { (Chakravorty } \\
\text { et al 1975) }\end{array}$ \\
\hline C-glass & Silver & $\begin{array}{c}\text { Sodium } \rightleftharpoons \text { silver } \\
+ \\
\text { reduction }\end{array}$ & $50-200$ & 400 & $\begin{array}{l}\text { (Sarkar et al } \\
\text { 1982) }\end{array}$ \\
\hline $\begin{array}{l}64 \mathrm{SiO}_{2} 26 \mathrm{~B}_{2} \mathrm{O}_{3} \\
10 \mathrm{Na}_{2} \mathrm{O} \\
(\text { mole \%) }\end{array}$ & & $\ldots$ & $50-200$ & 400 & $\ldots$ \\
\hline $\begin{array}{l}80 \mathrm{~V}_{2} \mathrm{O}_{5} 15 \mathrm{P}_{2} \mathrm{O}_{5} \\
5 \mathrm{Bi}_{2} \mathrm{O}_{3} \\
\text { (mole \%) }\end{array}$ & Bismuth & Reduction & $50-170$ & 450 & (Das 1982) \\
\hline $\begin{array}{l}64 \mathrm{SiO}_{2} 18 \mathrm{~B}_{2} \mathrm{O}_{3} \\
10 \mathrm{Na}_{2} \mathrm{O} 8 \mathrm{Bi}_{2} \mathrm{O}_{3} \\
\text { (mole })\end{array}$ & & $\ldots$ & $60-130$ & 500 & . \\
\hline $\begin{array}{l}50 \mathrm{BaO} 50 \mathrm{~B}_{2} \mathrm{O}_{3} \\
(\mathrm{wt} \%)+0.2 \mathrm{wt} \% \\
\text { Nickel }\end{array}$ & Nickel & $\begin{array}{l}\text { Organo- } \\
\text { metallic }\end{array}$ & $40-150$ & 250 & $\begin{array}{l}\text { (Datta and } \\
\text { Chkravorty 1983) }\end{array}$ \\
\hline
\end{tabular}

Table 6. Mechanical properties of glass-metal particulate composites prepared by hotpressing techniques

\begin{tabular}{|c|c|c|c|c|c|c|}
\hline $\begin{array}{l}\text { Glass } \\
\text { system }\end{array}$ & $\begin{array}{l}\text { Metal } \\
\text { species }\end{array}$ & $\begin{array}{c}\text { Diameter } \\
\text { of metallic } \\
\text { particles } \\
\mu \mathrm{m}\end{array}$ & $\begin{array}{l}\text { Volume } \\
\text { fraction } \\
\text { of metals }\end{array}$ & $\begin{array}{l}\text { Bending } \\
\text { strength } \\
\left(\mathrm{MN} / \mathrm{m}^{2}\right)\end{array}$ & $\begin{array}{l}\text { Fracture } \\
\text { toughness } \\
\left(\mathrm{MN} / \mathrm{m}^{3 ; 2}\right)\end{array}$ & Reference \\
\hline $\begin{array}{l}70 \mathrm{SiO}_{2} 16 \mathrm{Na}_{2} \mathrm{O} \\
14 \mathrm{Li}_{2} \mathrm{O}(\mathrm{wt} \%)\end{array}$ & Nickel & $44-63$ & 0.20 & $\begin{array}{c}83 \\
\left(50^{\circ} \cdot\right. \\
\text { increase })\end{array}$ & - & $\begin{array}{l}\text { (Stett and } \\
\text { Fulrath 1968) }\end{array}$ \\
\hline $\begin{array}{l}65 \mathrm{SiO}_{2} 8.5 \mathrm{Na}_{2} \mathrm{O} \\
26.5 \mathrm{~B}_{2} \mathrm{O}_{3}(\mathrm{wt} \\
0\end{array}$ & Tungsten & $3-13$ & 0.50 & $\begin{array}{c}155 \\
\left(172^{\circ} \circ\right. \\
\text { increase })\end{array}$ & - & $\begin{array}{l}\text { Nivas and } \\
\text { Fulrath 1970) }\end{array}$ \\
\hline $\begin{array}{l}50 \mathrm{SiO}_{2} 37 \mathrm{Na}_{2} \mathrm{O} \\
8 \mathrm{Al}_{2} \mathrm{O}_{3} 5 \mathrm{Li}_{2} \mathrm{O} \\
(w \mathrm{w})\end{array}$ & Aluminium & $100-120$ & $0 \cdot 20$ & - & $\begin{array}{l}\quad 60 \\
60 \times \\
\text { increase }\end{array}$ & $\begin{array}{l}\text { (Krstic et al } \\
\text { 1981) }\end{array}$ \\
\hline
\end{tabular}


comparable to that of the metal. The interfacial bonding has been somewhat enhanced by oxidising the metal particles partly before fabricating the composite. In table 6 the best set of data obtained in various glass-metal systems are summarised. In each case the glass composition chosen is such that its thermal expansion coefficient matches that of the corresponding metal. The amounts of increase in the bending strength or the fracture toughness over the base glass are shown within brackets in the appropriate column. The data also show that the strength of the composite is inversely proportional to the square root of the inter-particle spacing. It is to be noted that the composites studied so far contain metal particles having diameters of the order of a few microns and with an inter-particle spacing of similar magnitude. It will be interesting to investigate the behaviour of glass-metal composites having particle diameters of the order of 50-100 A. It is expected that with the techniques developed recently (Datta and Chakravorty 1983a) to make such composites it will be possible to study their mechanical behaviour.

\section{References}

Abeles B, Sheng P, Coutts M O and Arie Y 1976 Adv. Phys. 472200

Araujo R J 1977 in Treatise on materials science and technology (eds) M Tomozawa and R W Doremus (New York: Academic press) p. 71

Armistead W H and Stookey S D 1965 U.S. Patent 3108860

Arul Mozhi T and Chakravorty D 1982 J. Mater. Sci. Lett. 1426

Chakravorty D, Shuttleworth A and Gaskell P H 1975 J. Mater. Sci. 10799

Chakravorty D and Murthy C S 1975 J. Phys. D8 L162

Chakravorty D, Bandyopadhyay A K and Nagesh V K 1977 J. Phys. D 102077

Chakravorty D, Haranahaliı A R and Kumar D 1979a Phys. Status Solidi 51275

Chakravorty D, Keshavram B N and Venkateswaran A 1979b.J. Mater. Sci. 142991

Chakravorty D and Chakrabarti S 1980 J. Non-Cryst. Solids 38, 39295

Chakravorty D 1981 in Preparation and characterization of materials (eds) J M Honig and C N R Rao (New York: Academic Press) p. 515

Das G C and Chakravorty D 1980 J. Appl. Phys. 513896

Das G C 1982 Memory Switching and Optical Properties of Glass-Metal Microcomposites Ph.D. Thesis, IIT, Kanpur

Das G C and Chakravorty D 1982 J. Phys. D15 2255

Datta S, Bahadur D and Chakravorty D 1983 J. Phys. D (in press).

Datta S and Chakravorty D 1983 J. Mater. Sci. Lett. 2329

Krstic V V, Nicholson P S and Hoagland R G 1981 J. Am. Ceram. Soc. 64499

Landauer R 1978 AIP Conf. Proc. 402

McMillan P W 1979 Glass Ceramics (London, New York: Academic Press) p. 61

Nagesh V K, Tomsia A P and Pask J A 1983 J. Mater. Sci. 182173

Nivas Y and Fulrath R M $1970 \mathrm{~J}$. Am. Ceram. Soc. 53188

Pask J A and Fulrath R M 1962 J. Am. Ceram. Soc. 45592

Rawson H 1980 Properties and applications of glasses (Glass Science and Technology 3) (Amsterdam: Elsevier Publishing Co.) p. 218

Sarkar P, Kumar J and Chakravorty D 1982 J. Mater. Sci. 18250

Schreiber H D, Carpenter B E, Minnix L M, Balazs G B and Solberg T N 1983 Glastech. Ber. 56 K Band 2, 1017

Seward T P III 1975 J. Appl. Phys. 46689

Soffge F and von Horsten W 1981 Z. Phys. B42 47

Stett M A and Fulrath R M 1968 J. Am. Ceram. Sor. 51599

Stookey S D, Beall G H and Pierson J E 1978 J. Appl. Phys. 495114 